\title{
The Third Dimension of Victimization
}

\author{
Mary Graw Leary*
}

"[A] toolbox... protecting ... the virtual you.",

\section{INTRODUCTION}

The criminal law serves unique and critical purposes in society. It defines minimal conduct and safeguards commonly shared social interests. It has the potential to protect members of the community, prevent victimization, and punish those when such protection and prevention fail. Crime itself has been defined as a voluntary act that causes a social harm. ${ }^{2}$ Thus, the "social harm" caused by a criminal act rests at the very bedrock of criminal law. That social harm sought to be prevented has been defined as "the negation, endangering, or destruction of an individual, group, or state interest which is deemed socially valuable[.]"3 At its very core, the criminal law seeks to prevent endangerment of socially valuable interests.

New social values emerge as society evolves, as do to novel methods of victimizing people. Ideally, the criminal law identifies these new forms of victimization and, if they compromise a socially valuable interest, the law condemns such behavior as criminal. At times, this evolution has been the result of changed social values. For example, prohibition, the criminalization of adultery, and the non-criminalization of marital rape reflect formerly held social values that are no longer prevalent in modern society.

However, criminal law does not change only because of evolving social values. The criminal law must also respond to more structural changes in society that lead to innovative forms of victimization. For example, in its very early days, the criminal law of theft did not solely protect property interests, but a host of

Professor of Law, The Catholic University of America, Columbus School of Law. Special thanks to Tina Lee and Katherine Olson for their tremendous research assistance; to Steve Young the perfect reference librarian, and Rana Cullers for numerous drafts. A special word of thanks to Paul Cassell and the staff of the Ohio State Criminal Law Review for their patience and insight to devote a volume to crime victims. Dedicated to Sherri Bevan Walsh and her tireless efforts on behalf of victims.

What Are Elements of Sound Data Breach Legislation: Hearing on HIF027.170 Before H.R., Subcomm. on Commerce, Mfg, and Trade, Comm. On Energy and Commerce, 114th Cong. 22 (2015) (statement of Rep. Marsha Blackburn).

2 See, e.g., Albin Eser, The Principle of "Harm" in the Concept of Crime: A Comparative Analysis of the Criminally Protected Legal Interests, 4 DuQ. L. REV. 345, 386 (1965).

$3 \quad I d$. at 413. 
social interests implicating security. ${ }^{4}$ The advent of property ownership brought about the development of more sophisticated property crimes beyond larceny to include embezzlement, larceny by trick, and false pretenses. Similarly, criminal law once reflected only malum in se crimes. Consequently, malum prohibitum crimes developed as society became more complex and legislatures dealt with an increasing number of potential victimizations. While such structural changes are not commonplace, they demand significant shifts in the criminal law to protect the community and socially valued interests that emerge.

The time has come for such a shift. Traditionally, when addressing individual victims, the criminal law functions in two dimensions: crimes against the person and crimes against property. ${ }^{5}$ This modality is outdated. With the advent of the Internet, electronic commerce, and numerous digital platforms at the very core of modern American existence, modern American criminal law must recognize a third dimension of victimization of individuals: crimes against the digital extension of the person.

This article advocates for consideration of a restructuring of criminal laws at a basic level. It argues for the recognition of a third dimension of victimization. States must review criminal codes and restructure them to recognize the many new forms of victimization that are achieved digitally. Because of the uniquely pernicious harms of digital victimization, current criminal codes are insufficient. They fail to capture both the social value being protected and the harms accomplished through these digital victimizations. This article argues that one's digital presence can, in fact, be an extension of oneself. As such, one's digital self can be harmed in ways that are distinct from our current understanding of personal or property crimes. This form of victimization should be recognized by the criminal law, and the social interests in protecting individuals in this dimension should be reflected in the criminal law.

Part II explores the purpose of criminal law and argues that criminal codes do not achieve their purpose when they fail to sufficiently address these digital victimizations. Part III describes the emergence of the digital self and the unique harms that the digital self suffers. Part IV explores areas of criminal law that have made similar adaptations, arguing that this history supports recognizing this new paradigm. Part $\mathrm{V}$ analyzes current de facto recognitions of the digital self in the criminal law. Finally, Part VI describes what form such a criminal law restructuring should take in order to reflect these modern values and fulfill the promise of criminal law in society. It advocates for adding a third dimension of

4 George Fletcher, Rethinking Criminal Law §1.3.1, at 31 (Boston: Little Brown, 1st ed. 1978). But see Eser, supra note 2, at 349 (arguing that the historical context of defining "harm" in the criminal realm has become irrelevant).

5 See e.g., National Incident-BAsed Reporting System, Crimes Against Persons, PROPERTY, AND SOCIETY (2011), http://www.fbi.gov/about-us/cjis/ucr/nibrs/2011/resources/crimesagainst-persons-property-and-society). While most criminal codes contain other forms of crime, they usually involve victims who are not individuals. For example, terrorism and treason are crimes against the state itself. This article addresses only crimes as they relate to individuals. 
victimization: crimes against the digital person as an extension of the physical person.

\section{THE PURPOSE OF THE CRIMINAL LAW}

It is axiomatic that the criminal law is distinct from civil law. Through litigation, civil laws allow members of the community to obtain redress from each other. The civil law is almost procedural and provides a path of legal redress to replace self-help. While an important component of society, the civil law is, in some senses, less "majestic" than the criminal law in that the criminal law speaks on behalf of society.

The criminal law produces a conviction, not a decision. As Henry Hart noted over half a century ago, a conviction is "a formal and solemn pronouncement of the moral condemnation of the community." The criminal law reflects both the shared values of a community and the shared belief that endangering such values demands, not only redress, but community condemnation. As a practical matter, the remedies in the context of the civil law are often available only to those who have engaged in a cost-benefit analysis of seeking redress and have determined they have the capability (financial, emotional, or temporal) to seek redress.

In the context of personal crimes, however, the criminal law signifies much more than a procedural pathway but also a substantive one. Society pursues the criminal law because a suspected wrongdoer has injured society as a whole, in addition to harming an individual, by breaking the social code. The cases are captioned with the charging party as the State, the People, the Commonwealth, or the United States. This is far more than symbolic: it signifies that the community itself brings a criminal action against a defendant because that defendant has harmed a member of the community, and the community will not stand for such an infraction. Therefore, the criminal law is not simply a procedural mechanism for redress, but it is a substantive one because the community imposes the criminal law against an offender to protect one of its members from victimization.

Recognizing this distinction, one must examine the goals of such a system of redress on behalf of the community. As a threshold matter, the criminal law contains many distinct goals, including contributing to social order, preventing crimes, protecting victims, inducing socially positive behavior, punishing socially negative behavior, and rehabilitating those who have committed a crime. Although characterized by many goals, these principles do not necessarily wholly exclude the others. ${ }^{8}$ Central to this system is the judgment of the community. ${ }^{9}$

6 Henry M. Hart, Jr., The Aims of the Criminal Law, 23 LAW \& COMTEMP. ProbS. 401, 405 (Summer 1958), reprinted in CRIME, LAW, AND SOCIETY 61, 65 (Abraham S. Goldstein \& Joseph Goldstein eds., 1971).

$7 \quad I d$. at 61.

$8 \quad I d$. at 62.

$9 \quad$ Id. at 65. 
[T] he criminal law has an obviously significant and, indeed, a fundamental role to play in the effort to create the good society. For it is the criminal law which defines the minimum conditions of man's responsibility to his fellows and holds him to that responsibility. ${ }^{10}$

Therefore, one primary goal of the criminal law is to reflect a moral code of acceptable and unacceptable behavior within the community. ${ }^{11}$ Regarding personal crime, however, the acceptability of the behavior is related to the finding that the "conduct is deemed sufficiently injurious to interest of the individual or community to warrant the protection of the criminal law." 12 Once the social injury that the society seeks to condemn is identified, the criminal law reflects a shared moral code.

Embedded in this concept is that the criminal law seeks to protect society as a whole and its individual members from harm. ${ }^{13}$ This is accomplished first by defining conduct that is deemed socially injurious and then seeking to induce "conformity to the rule." 14 That inducement can be achieved through this definition as well as punishment when the prevention of crime fails. ${ }^{15}$ Thus, the criminal law functions to "equip[] the proposed social order with adequate tools to discourage undesired conduct[.]"16

These several complementary purposes of the criminal law cannot be achieved if the code itself is without legitimization. Hence, the code must reflect commonly shared values. As Oliver Wendell Holmes noted, "[t]he first requirement of a sound body of law is, that it should correspond to the actual feelings and demands of the community, whether right or wrong." ${ }^{\prime 7}$ The criminal law, therefore, fails when it does not reflect commonly understood harms.

The current criminal law system does not adequately reflect commonly understood harms. As the next sections elaborate, the digital world has opened a

10 Henry M. Hart, Jr., The Aims of the Criminal Law, 23 LAw \& CONTEMP. ProBs. 401, 410 (Summer 1958).

11 Wharton's CRiminal LAW $\S 1$, at 10-12 (15th Ed. 1993).

12 Id. at $\S 1$.

13 Livingston Hall \& Sheldon Glueck, Cases on Criminal Law And its EnForcement 8 (1951).

14 Oliver Wendell Holmes, Jr., Theories of Punishment and the External Standard (1881), reprinted in CRIME, LAW, AND SOCIETY 27, 32 (Abraham S. Goldstein \& Joseph Goldstein eds., 1971); see also Hart, supra note 6, at 67 ("The commands of the criminal law are commands which public interest requires people to comply with.").

15 Wharton's, supra note $11, \S 1$, at 10-12.

16 Hart, supra note 6, at 68.

17 Holmes, supra note 14, at 27; see also Paul H. Robinson, Geoffrey Goodwin, Michael Reisig, The Disutility of Injustice, 85 N.Y.U. L. REV. 1940, 1942 (2010)(noting the importance of criminal law earning a reputation of moral authority by reflecting a community's "shared intuition of justice."). 
new dimension of victimization previously not seen in society. While many other disciplines have documented the unique social harms resulting from various forms of victimization, the criminal law has not sufficiently followed in this trend. This is due, in part, to the unique role of the criminal law, which demands caution before recognizing new forms of victimization. "The law draws its life juices from custom and public opinion. It cannot be too far in advance of these without

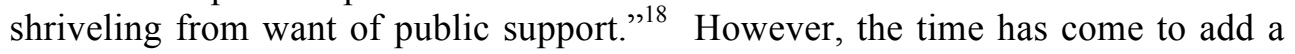
third dimension of victimization to our criminal codes: the victimization of the digital self.

\section{THE UniQUe HARMS To THE Digital SELF}

\section{A. The Digital Self is an Extension of the Physical Self}

Criminal codes typically refer to "personal crimes" or "crimes against the person" to specifically reference crimes against the physical persons. For centuries this categorization was sufficient. When an individual was assaulted, threatened, or endangered, the harm was generally to his or her physical body.

The concept of the "digital self" or "digital person" arose from the early days of the Internet and the increased role of the digital world in everyday life. This concept, referred to as one's "digital footprint," that leaves traces throughout the digital world. It includes information individuals themselves have placed into the digital world through social networking profiles, blog posts, and other forms of self-created digital content that combine to form a "digital profile." It also includes, however, information collected about individuals without their consent, even including information placed on the Internet connected to the individual's identity but not endorsed by the individual. Examples of this type of information include false information, incorrect information, or intentionally hurtful information. While the individual's physical self and the individual's digital self were at one time two distinct personas, over time, the digital and physical selves have arguably merged - becoming somewhat indistinguishable.

The overlap and blurring of the individual's digital and physical selves have manifested in a number of ways. For example, teens primarily communicate not through in person connections or even through a telephone, but through texting. ${ }^{19}$ One of the most primary forms of communication is through social media-one digital profile sharing information with a whole network of digital profiles. ${ }^{20}$

18 HALl \& GLUECK, supra note 13, at 10.

19 See David S. Ardia, Reputation in a Networked World: Revisiting the Social Foundations of Defamation Law, 45 HARV. C.R.-C.L. L. REv. 261, 270-71 (2010); Amanda Lenhart, Teen, Social Media, and Technology Overview, PEw RESEARCh CENTER, 4-6 (2015) (noting the prevalence on teen texting as a form of communication), http://www.pewinternet.org/2015/04/09/teens-socialmedia-technology-2015/.

20 See Ardia, supra note 19, at 303-10. 
Usually, individuals voluntarily create social profiles and place these digital versions of themselves online. However, employers often require their employees to place profiles through social platforms such as LinkedIn or Facebook for employment purposes. ${ }^{21}$ In this way, an employee's "professional self" takes on a digital form, as well as a physical one, in the business world.

Basic components of daily life now occur online, including bill paying, banking, and video and audio communications. In short, our digital selves are no longer compartmentalized from our physical selves; they are, in fact, extensions of ourselves. Massachusetts Institute of Technology (MIT) scholar, Sherry Turkle, describes it this way:

I once described the computer as a second self, a mirror of mind. Now the metaphor no longer goes far enough. Our new devices provide space for the emergence of a new state of the self, itself, split between the screen and the physical real, wired into existence through technology. ${ }^{22}$

Many other scholars have recognized Turkle's concept of the "new state of self." Daniel Solove recognized a similar concept when he coined the term "digital dossier." 23 John Palfrey and Urs Gasser describe the "digital dossier" as all the personally-identifiable digital information associated with one's name, and they further discuss one's digital identity as a subset of information "composed of all those data elements that are disclosed online to third parties, whether it is by [one's] choice or not." ${ }^{24}$ Furthermore, Palfrey and Gasser discuss the implications of this reality regarding "digital natives." "[W]e are just at the beginning of the digital age. ... Digital Natives will be the first to experience the compounding effects of the creation of identities and digital dossiers over a long period of time.. .. The extent of the damage caused by harmful information - in terms of who can access it, when, how, and over what period of time - continues to increase as the use of technology increases." 25

21 See, e.g., Lisa Quast, Recruiting, Reinvented: How Companies Are Using Social Media In The Hiring Process, Forbes (May 21, 2012, 9:30 AM), http://www.forbes.com/sites/lisaquast/2012/05/21/recruiting-reinvented-how-companies-are-usingsocial-media-in-the-hiring-process/.

22 Sherry Turkle, Alone Together: Why We Expect More from Technology and Less FROM EACH OTHER 16 (2012).

23 Daniel J. Solove, Digital Dossiers and the Dissipation of Fourth Amendment Privacy, 75 S. CAL L. REV. 1083, 1095 (2002) (describing digital dossiers as "digital biographies, a horde of aggregated bits of information combined to reveal a portrait of who we are based upon what we buy, the organizations we belong to, how we navigate the Internet, and which shows and videos we watch").

24 John Palfrey \& Urs Gasser, Born Digital: Understanding the First Generation of Digital NATives 40 (2010).

25 Id. at 62-63 (defining digital native as a person born in the digital age (post 1980) who has access to net-worked technologies, with strong computer skills and knowledge). 
While an individual once had a separate physical self and a distinct digital self, these two worlds have now merged together to some extent. Global communication has led to the reality that entities once so personal, such as reputation and privacy, are no longer related to concepts of physical space. ${ }^{26}$ This boundary between the physical self and the digital self continues to dissipate. ${ }^{27}$ As discussed infra, the digital self can be harmed and that harm, in turn, can harm the actual self. The most common examples of this "harm cycle" include cyber bullying, threats, stalking, "revenge pornography" or "involuntary pornography," and identity theft. This is especially true for younger people who develop their social identities through their digital selves, which can heavily influence the shaping of their actual self. ${ }^{28}$ This evolution from separate physical and digital selves to a merged continuous sense of self demonstrates two realities. First, the digital person is an extension of oneself. Second, as a consequence, a person can suffer harm as a result of an attack on the digital person.

\section{B. The Harms to the Digital Self are Uniquely Pernicious and Inadequately Recognized in the Criminal Law}

Given the examples above, one might argue that the criminal law already recognizes harms to the person, and there is no need to alter the criminal law to recognize an entirely new category of victimization. However, such a view fails to recognize that the harms to the digital person, as an extension of oneself, are uniquely pernicious and deserve a separate and distinct category.

When crime was limited to the physical world, it was limited to the finite world. For example, a physical restraint, legal protective order, or the relocation of the victim could thwart a stalker. Today, that stalker can now utilize the Internet to find the victim, continue to stalk the victim online, and effectively always be within reach of the victim. "In the past, much personal information was publicly inaccessible because of practical impediments. The Internet is largely eliminating those impediments." 29 While a stalking victim in the past may have felt as though the stalker was omnipresent, today the stalker is virtually omnipresent. This kind of "omnipresent" harm is distinctly different and unique from traditional concepts of stalking.

26 Ardia, supra note 19 , at 306.

27 Jagdish N. Sheth \& Michael R. Solomon, Extending the Extended Self in a Digital World, 22 J. MARKETING THEORY \& PRAC.125-26 (2014) (discussing the concepts of digital fusion between the physical self and online life as facilitated through technology).

28 Shanyang Zhao, The Digital Self: Through the Looking Glass of Telecopresent Others, 28 SYMBOLIC INTERACTION 387, 395 (2005) (discussing formation of self-conceptualization as it relates to the digital self and noting that it is "impossible to separate the digital self from other aspects of a person's self-repository").

29 Ardia, supra note 19, at 262; U.S. Dep'T OF Justice, Report to Congress ON STAlking AND DOMESTIC Violence, 2 (May 2001). 
Cyber bullying offers another illustration. In the past, a victim of bullying would be concerned that the bully would injure the victim's reputation in a given, finite community such as a school, neighborhood, or town. For example, a young person bullied by classmates may believe that the bullying would occur only at school. "Global communications networks such as the Internet have made reputation more enduring and yet more ephemeral. Reputation is more enduring because information about us, whether good or bad, can exist - and be easily retrievable-forever." ${ }^{, 30}$ Indeed, information injurious to individuals literally exists for all time in the form of blog posts, social networking statements, and "vast online data repositories" that can be accessed at any time by any individual. ${ }^{31}$ Again, while in the past a victim of bullying may have felt as though the entire world was being told something personal, today a victim is being injured before the world. These "cyber attackers," whether cyber bullies, cyber stalkers, or other cyber criminals, take advantage of the free anonymous Internet that allows them to victimize their targets in real time from anywhere in the world. ${ }^{32}$

Similarly, crimes such as identity theft have taken on a more universal omnipresent character. This crime once required an offender to physically obtain a credit card and physically use it in the physical world, thus incurring some risk. Now, an offender can obtain the credit card number and utilize it to buy items online or exploit the information he can derive from it without ever physically possessing the card or identification. ${ }^{33}$

The Supreme Court has explicitly recognized this extension of self in the context of sexually-abusive images of children, commonly referred to as "child pornography." In finding that a victim of such images is harmed again each time a possessor of such images views her image, the Supreme Court stated that "[i]t is common ground that the victim suffers continuing and grievous harm as a result of her knowledge that a large, indeterminate number of individuals have viewed and will in the future view images of sexual abuse she endured." 34 In fact, the Court characterized the viewing of these images as repeating the sexual abuse crime itself. $^{35}$ While the Court had previously acknowledged that such images may be more harmful to victims than the initial abuse, the Court specifically noted that the Internet itself changed the nature of the harm. ${ }^{36}$

30 Ardia, supra note 19, at 262.

31 Id.

32 Jacqueline D. Lipton, Combatting Cyber-Victimization, 26 Berkeley TECH. L. J. 1103, 1111-14 (2011).

33 See, e.g., S.B. 3566, 201st Gen. Assemb., Reg. Sess. (N.Y. 2015).

34 Paroline v. United States, 134 S. Ct. 1710, 1726 (2014).

35 Id. at 1717.

36 New York v. Ferber, 458 U.S. 747, 759 \& n.10; Paroline, 134 S. Ct. at 1717 ("Because child pornography is now traded with ease on the Internet, "the number of still images and videos memorializing the sexual assault and other sexual exploitation of children, many very young in age, has grown exponentially."'). 
The law has at times given voice to the digital harms suffered. However, given the profound and unique harm associated with this form of victimization, the traditional law and its categorization are too limiting and inadequate. ${ }^{37}$

\section{THE CRIMINAL LAW ADAPTS}

It is not novel for the criminal law to embark on such a fundamental shift. Given some of the aforementioned purposes of the criminal law, it is necessary that the criminal law reflects the contemporarily shared values of the present. That said, the criminal law is not the only social structure to address social ills, and legislatures are wise to move cautiously when considering significant alterations. The law cannot respond to every social ill through criminalization. Given the slow progress of legislative efforts, many forms of victimization will have changed between the time of the legislation's conception and its passage, thus making the law obsolete before it takes effect. This reality is compounded when the need for change is driven by rapidly evolving technologies.

Nonetheless, when the societal landscape has gone through substantial changes, the criminal law must do so as well. This has occurred many times in history on very fundamental levels. It has also occurred with more minor but still significant changes with technology, such as theft, stalking and harassment, and reputational harm.

Criminal laws deal not only with private wrongs, but also address public wrongs. As such, when society evolves and recognizes a form of victimization as negating a socially valuable interest, the criminal law must change to address this shift in societal perspective.

The concept of a public wrong is the product of a social evolution, and whether an act has been or is deemed to be a public injury or menace depends upon the stage of civilization and the conditions which confront a people.... Different conditions thus become the cause of different laws. ${ }^{38}$

These changes can be fundamental. William Nelson's study of the transformation of the criminal law during the Revolutionary Era is a clear demonstration of this. ${ }^{39}$ Between 1760 and 1810, the criminal law in the colonies radically shifted from the primary purpose of enforcing Puritan laws of morality to the more modern goal of protecting people and property. ${ }^{40}$ Blackstone had

37 See generally Lipton, supra note 32, at 1111-12.

381 WM. L. BURDICK, THE LAW OF CRIME $\$ 3$ (1946).

39 William E. Nelson, Emerging Notions of Modern Criminal Law in the Revolutionary Era, 42 N.Y.U. L. REV. 450 (1967), reprinted in CRIME, LAW, AND SOCIETY 73 (Abraham S. Goldstein \& Joseph Goldstein eds., 1971).

$40 \quad$ Id. at 74. 
developed in Great Britain a concept of classifying crimes that had been largely ignored in the colonies in favor of using the law to regulate sin. However, "[ $t]$ he years after the revolution brought forth vast changes in attitudes toward crime and the criminal. Prosecutions for various 'immoral' actions ceased while economically motivated crimes and prosecutions, greatly increased." 41 This increase was driven not only by evolving standards, but also by the practical realities of daily life. Society was seeing an increase in economic disparity and the urban poor, which society saw as a cause of an increased number of thefts. Moreover, it reflected a new consideration in the criminal law: assessing the victimization aspects of a suspect's behavior and thereby determining that to be worthy of condemnation. ${ }^{42}$ The criminal law was seen as having the purpose of preserving social order and the integrity of property, not as preserving morality per $\mathrm{se}^{43}$

Indeed the evolution of theft and larceny itself demonstrates a significant societal shift in the criminal law. Interestingly, in its early history, theft was not criminalized solely as a property concept due to the lack of actual property ownership among the masses and the common people. While robbery was punishable, the crime was developed in the only framework essentially available in the common law: a crime against a person. ${ }^{44}$ With, among other events, the major societal transformation of property ownership, the courts began to recognize and expand the crime of larceny. However, as the concept of property further developed, the common law kept molding the crime of larceny to fit into new kinds of theft, such as theft by false pretense and larceny by trick. ${ }^{45}$ With the growth of more complex business transactions and various methods of depriving victims of property, the criminal law developed even further to include fraud and other situations to supplement the crime of theft. ${ }^{46}$

Just as a call for a change in the criminal law to recognize a new societal harm is not novel, the notion that technology drives some fundamental changes is also not new. Defamation law, although not criminal, offers a clear example. This body of law began in feudal times, expanded with the advent of the printing press, and later was constitutionalized by the Supreme Court with the emergence of broadcast and mass media. ${ }^{47}$ Ardia argues that this body of law is again at a crossroads with the decrease of broadcast media but with the increase in online platforms such as social networking sites, blogs, and social media accounts. $\mathrm{He}$

$41 \quad$ Id. at 77.

42 Id. at 82 ("The criminal in 1810 was no longer envisioned as a sinner against God, but rather as one who preyed upon his fellow citizens.").

$43 \quad I d$. at 83 .

44 HALL \& GLUECK, supra note 13 , at 165.

45 See id. at $165-71$.

46 See id. at 165.

47 Ardia, supra note 19, at 262. 
further comments that these new developments have "profoundly altered" defamation law, and this body of law needs to follow suit. ${ }^{48}$

While not categorized as a crime, defamation law is not wholly unrelated to the crimes of cyber stalking/harassment or threats. The traditional versions of these crimes were once limited to the physical world; however, new technologies such as online and digital communications have altered the landscape with the criminal law following. Before the 1990s, stalkers victimized people, mostly women, but law enforcement was without a mechanism to respond. These victims suffered profound harms relating to stress, fear, and financial cost of relocation or trying to escape the reach of the stalkers. However, since these offenders had not physically harmed the victims, no remedy was available to the victims or to law enforcement. ${ }^{49}$ This example demonstrates a situation in which the victims were clearly harmed, but because such harms were previously only conceptualized as bodily harm, the law was inadequate and provided no relief or redress for the victims. Therefore, the first anti-stalking laws emerged in the 1990s, and subsequently, forty-nine states and the federal government had an anti-stalking or anti-harassment crime by $1996 .{ }^{50}$ Thus, the law adapted to a new reality of the crime of stalking through understanding the crime's parameters and recognizing that the motive of offenders was not always violence but also included elements of obsession, real or imagined relationships, and control. As explored in later sections, the criminal further adapted when offenders started to utilize new technologies in the commission of the crime and expanded to include cyber stalking and cyber harassment laws. ${ }^{51}$

Therefore, the idea that society should consider significantly altering the criminal code by recognizing the digital person as an extension of oneself through which the actual person can be profoundly harmed, is not revolutionary. Similar transformational shifts occurred, such as expanding the concept of crime, which was previously limited to include crimes against a person to include crimes against property. Such alterations have also taken place in smaller contexts, such as understanding the societal harms of crimes like harassment, stalking or threats, and how the criminal law has adjusted to recognize such harms. Finally, technological shifts, such as mass media, the Internet, cellular devices, can create new harms experienced by victims as well as new socially-protected interests. As such, the criminal law should recognize this third dimension of victimization within the context of personal crime.

48 Id. at 273

49 Dep't of Justice, Nat'l Inst. of Justice, Domestic Violence, Stalking, and Antistalking Legislation: An Annual Report to Congress Under the Violence Against WOMEn ACT 5 (1996) [hereinafter NIJ REPORT TO CONGRESS].

50 Id.

51 See discussion infra Section V.C. 


\section{THE LAW RECOGNIZES EXTENSIONS OF THE SELF IN A VARIETY OF CONTEXTS}

The suggestion of recognizing the digital person as an extension of the physical person is not as radical as it may first seem. The criminal law has a rich history of understanding harms to the person that occur outside the physical realm. Crimes, such as sexually-abusive images of children, stalking and harassment, and identity theft, to name a few, are instances where the criminal law has recognized a relationship between the person and the extension of the person beyond his or her physical body. Accordingly, recognizing a separate category of personal crime, i.e. that the digital person is an extension of the person, is a natural outgrowth of this precedent. The distinction between these isolated cases of the past and the need for a more contemporary, comprehensive approach highlight the nature of our inter-connected world. With each of these aforementioned changes in the criminal law, the law was responding to a new, but narrow, form of victimization. With the advent of the Internet and digital communications, all people have the potential to create a digital presence as an extension of themselves where this presence has emotional, financial, and commercial implications. As such, its protection, particularly when understood as an avenue to the actual self, is a socially-valuable interest.

The following section examines some areas where the law has recognized a form of a person's digital extension. These will include sexually abusive images of children, "revenge pornography, also known as non-consensual pornography, identity theft, and stalking/harassment. While not an exhaustive list, these examples support the reality that the law has already recognized such extensions of the person in particular context. The time has come for the law to do so in a more comprehensive manner.

\section{A. Sexually Abusive Images of Children}

In 1982, the Supreme Court categorized sexually abusive images of children as unprotected speech. ${ }^{52}$ From the very beginning and throughout this jurisprudence, the Court recognized that one of the reasons these images are unprotected is the fact that the images themselves are harmful to the children depicted in them. More recently, the Supreme Court explicitly advanced this position by unequivocally recognizing that the children themselves are revictimized every time a possessor views the images. ${ }^{53}$ A review of the Court's jurisprudence over these intervening two decades reflects a clear understanding

52 New York v. Ferber, 458 U.S. 747 (1982). The Supreme Court referred to these images as "child pornography" in 1982, as that was the accepted term. Since that time, however, the preferred term is Sexually Abusive Images of Children. See e.g., Mary Graw Leary, Death to Child Erotica: How Mislabeling the Evidence Can Risk Inaccuracy in the Courtroom, 16 CARDOZO J.L. \& GENDER 1, n.1 (2009).

53 See Paroline v. United States, 134 S. Ct. 1710, 1717 (2014). 
that the images themselves harm the actual person and, by implication, that those images are in some way an extension of the person.

In New York v. Ferber, the Court articulated several reasons to find sexually abusive images of children unprotected. These reasons reflected what Professor Audrey Rogers has labeled the "dual justification" for not affording First Amendment protection to sexually abusive images of children: a concern for the actual and threatened harm to children inherent in both the production and distribution of sexually abusive images of children. ${ }^{54}$ The Ferber Court specifically recognized that the "use of children as subjects of pornographic materials is harmful to the psychological, emotional, and mental health of the child." 55 But more importantly, the Court saw that children were harmed by the images' existence themselves, not just by the circumstances surrounding their production. The Court noted that the images were "permanent records of children's participation and the harm to the child is exacerbated by their circulation." According to the Court, the "nature of the harm" was not the exploitive production, but the "visual[] depict[ion] [of] sexual conduct by children below a specified age." the images may be the greater harm to these children:

Pornography poses an even greater threat to the child victim than does sexual abuse or prostitution. Because the child's actions are reduced to a recording, the pornography may haunt him in future years, long after the original misdeed took place. A child who has posed for a camera must go through life knowing that the recording is circulating within the mass distribution system for child pornography. ${ }^{58}$

In 1990, the Court furthered this understanding of the images themselves harming children when it found in Osborne v. Ohio that the possession of sexually abusive images of children was also not protected by the First Amendment. ${ }^{59}$ In line with the rationale in Ferber, the Osborne Court saw that the very existence of these images negated a socially valued interest because this "pornography's continued existence causes the child victims continuing harm by haunting the children in years to come." 60

In a slight deviation from this jurisprudence, the Court in Ashcroft v. Free Speech Coalition held that that virtual child pornography did not fall under the

54 Audrey Rogers, Child Pornography's Forgotten Victims, 28 PACE L. REV. 847, 856 (2008).

55 Ferber, 458 U.S. at 758.

$56 \quad$ Id. at 759 (emphasis added).

57 Id. at 764 .

58 Id. at 759 n.10 (emphasis added) (citing David P. Shouvlin, Preventing the Sexual Exploitation of Children: A Model Act, 17 Wake Forest L. Rev. 535, 545 (1981)).

59 Osborne v. Ohio, 495 U.S. 103 (1990).

$60 \quad$ Id. at 111 . 
Ferber definition of child pornography or sexually abusive images of children. However, the Court emphasized that this analysis did not diminish the Court's previous understanding that the images themselves harm the children. ${ }^{61}$ The thrust of the Ashcroft Court's opinion focused on the first justification articulated in Ferber: the harm to children in production of such images. Accordingly, the Ashcroft Court concluded that no harm occurred in the production of such images because the children in the images were virtual and not real children. However, the Court did not retreat from its articulation that the images themselves cause harm. In fact, the Court noted that morphed child pornography-i.e. sexually abusive images of children created from a non- pornographic image of an actual child - are more akin to the concerns in Ferber than are virtual images that do not contain any depiction of real children. ${ }^{62}$ That is to say that the Court drew a distinction between images that are digital extensions of actual people (morphed and real child images) and those that were not.

If there was any doubt of the Court's position regarding the social harm caused by the existence of the images, it was removed in the recent case of Paroline v. United States. Although the Paroline Court did rule against the victims when it held that a victim may not receive restitution from a possessor of sexually abusive images of children without first establishing the possessor proximately caused the harm, it also explicitly recognized the victims of images are acutely harmed with the knowledge of each viewing of those images. The socially valuable interest that is compromised with the possession of such images was most clearly articulated by the following:

The full extent of this victim's suffering is hard to grasp. Her abuser took away her childhood, her self-conception of her innocence, and her freedom from the kind of nightmares and memories that most others will never know. These crimes were compounded by the distribution of images of her abuser's horrific acts, which meant the wrongs inflicted upon her were in effect repeated; for she knew her humiliation and hurt were and would be renewed into the future as an ever-increasing number of wrongdoers witnessed the crimes committed against her. ${ }^{63}$

Moreover, the Court explicitly endorsed the view that possession of such images and the subsequent viewing of these images was itself an exploitive act that revictimized the child. ${ }^{64}$ "It would be inconsistent ... to apply the statute in a way that leaves offenders with the mistaken impression that child pornography possession (at least where the images are in wide circulation) is a victimless

\footnotetext{
61 Ashcroft v. Free Speech Coal., 535 U.S. 234, 250 (2002).

$62 \quad$ Id. at 242.

63 Paroline v. United States, 134 S. Ct. 1710, 1717 (2014) (emphasis added).

${ }^{64} \quad I d$. at 1727.
} 
crime." ${ }^{65}$ The only way that such could be the case is if the treatment of the image was considered an extension of the self. Thus, the Court's child exploitation jurisprudence clearly articulates that a person is victimized when their digital self is exploited.

\section{B. Non-Consensual or "Revenge" Pornography}

A rapidly emerging area of the criminal law that clearly demonstrates this recognition of the harm to the person through the targeting of the digital person is the area of non-consensual or "revenge" pornography. "Re "Revenge pornography" refers to a nude or sexually explicit image that is shared publicly without the consent of the victim. ${ }^{67}$ It often references an intimate image or video that was initially shared between two people in an intimate relationship with the expectation that it will remain private. ${ }^{68}$ However, the images are not always produced with the consent of the victim, or with the knowledge of any of the subjects depicted. ${ }^{69}$ They can be shared by the victim or taken from her by a hacker. ${ }^{70}$

Regarding distribution, this dissemination can take many forms including sharing the image with other people; posting the image on a web site designed to injure such victims; posting the image and accompanying it with identifying and/or disparaging remarks regarding the victim; mass sharing to communities such as classmates, cities and towns, groups; or targeting its distribution to specific persons such as employers, family members, and paramours. ${ }^{71}$ Often such a distribution occurs after the end of an intimate relationship. However, non-consensual

65 Id.

66 When this issue first reached public discussion, it was labeled as "revenge porn." However, with legislation and scholarship addressing the issue, some have preferred the label "nonconsensual pornography." Each term is both descriptive and inadequate. "Revenge" connotes the frequent intent behind this behavior. However, it also suggests a motive that may not necessarily be present. Much more problematic and improper is the use of the word "porn," which is a slang term, and slang, by definition, connotes something light, flippant, or harmless. Mary G. Leary, Worth a Few Appalled Words, LegAL TIMES (Dec. 17, 2007) (discussing the problems of the word "porn"). "Non-consensual" is arguably more inclusive but focuses on the behavior of the victim, not the behavior of the offender. This article will use the terms "revenge pornography" and "nonconsensual pornography" interchangeably and consistent with the definition that follows.

67 Taylor Linkous, It's Time for Revenge Porn to Get a Taste of Its Own Medicine: An Argument for the Federal Criminalization of Revenge Porn, 20 RiCH. J.L. \& TECH. 1, 6 (2014).

68 See, e.g., Adrienne N. Kitchen, The Need to Criminalize Revenge Porn: How a Law Protecting Victims Can Avoid Running Afoul of the First Amendment, 90 CHI.-KENT L. REV. 247, 247-48 (2015); Aubrey Burris, Hell Hath No Fury Like a Woman Porned: Revenge Porn and the Need for a Federal Nonconsensual Pornography Statute, 66 FLA. L. REV. 2325, 2327-28 (2014).

69 Burris, supra note 68, at 2333-34; Kitchen, supra note 68 at 247-48.

70 Linkous, supra note 67 , at 3.

71 See id. at 3-4. 
pornography events have occurred when an offender hacks into an account of the victim and shares the pictures. ${ }^{72}$

Of particular concern are situations in which the images are posted on websites designed for public sharing such as IsAnyoneUp.com, UGotPosted.com or MyEx.com. ${ }^{73}$ One such website owner actually required the subject's identifying information for submission of images to UGotPosted.com, and then charged victims hundreds of dollars to remove them through changemyreputation.com. ${ }^{74}$

Regardless of the exact form of the victimization, the harm is very tangible and unique to these victims. Victims experience extreme invasions of privacy which cause them to suffer severe psychological trauma, emotional trauma, personal trauma, professional ruin, and property losses. ${ }^{75}$ Ultimately, victims' reputations are destroyed. ${ }^{76}$ Similar to victims of sexually abusive images of children, victims of revenge pornography suffer the perpetual harm of their explicit images being available on the Internet for eternity without an ability to retrieve or delete them. ${ }^{77}$ This brings the psychological trauma of wondering whether every person with whom they interact has seen these images.

When the images are also connected with a phone number or other identifying information, the harm becomes more profound as they then contend with cyber harassment and stalking. ${ }^{78}$ Victims are often stalked both in person and electronically, being subjected to receiving massive amounts of pornography or obscene messages. $^{79}$ Additionally, these victims suffer property losses. They report having lost their jobs and being unable to obtain new positions. ${ }^{80}$ They suffer other forms of property loss including the costs of moving, changing their names, telephone numbers, and lives. ${ }^{81}$

As this trend grew, as well as the public discovery of websites such as IsAnyoneUp.com dedicated to this anti-social behavior, the criminal law adjusted. Although not a crime against the physical body or property per se, many states

72 See Mary Anne Franks, Combatting Non-Consensual Pornography: A Working Paper 3 (Sep. 7, 2014), http://papers.ssrn.com/sol3/papers.cfm?abstract_id=2336537.

73 E.g., Linkous, supra note 67, at 6-7; Danielle Citron and Mary Anne Franks, Criminalizing Revenge Porn, 49 WAKe Forest L. ReV. 345, 368 (2014).

74 Linkous, supra note 67, at 15.

75 Citron and Franks, supra note 73, at 351-353; Snehal Desai, Smile for the Camera: The Revenge Pornography Dilemma, California's Approach and Its Constitutionality, 42 HASTINGS Const. L.Q. 443, 445 (2015).

76 Franks, supra note 72 , at 3-4.

77 Id.; Linkous, supra note 67, at 13.

78 Kitchen, supra note 68, at 248.

79 Mary Anne Franks, Unwilling Avatars: Idealism and Discrimination in Cyberspace, 20 Colum. J. Gender \& L. 224, 245 (2011) (hereinafter Avatars).

80 Franks, supra note 72 , at 4.

${ }^{81} \quad I d$. 
clearly recognize the social harm of revenge pornography. As a result, approximately fourteen states have adopted legislation to criminalize this behavior. This body of statutes is a clear example of the criminal law recognizing the abuse of the digital person as an abuse of the actual person because that image or persona is an extension of the self.

These statutes vary widely. Some statutes require the intent to cause harm at the time of dissemination. Others do not do so. Some statutory reforms include a private right of action, while others respond with a purely criminal reaction. Some of the statutes limit criminal liability to the initial distributor. However, there is one common theme amongst these varying state statutes: implicit in many of these statutes is the recognition of the digital extension of the person. For example, New Jersey's legislature recognized that "people have a right to control the observation of their most intimate behavior under circumstances where a reasonable person would not expect to be observed." ${ }^{\prime 2}$ California's law recognizes the "extreme humiliation of victims." 83 Delaware's statute also recognizes the property loss and notes the "person depicted unwillingly becomes sexual entertainment for strangers and the person's career and standing within the community can be negatively impacted." $" 84$ All of these state findings exemplify an understanding that images are an extension of the victims, which by themselves, cause measurable social harms when exploited.

\section{Stalking, Harassment, and Cyber Bullying}

Within the context of crimes such as stalking, harassment, bullying, and threats, the criminal law has recognized harm to the person beyond the victim's physical person. It recognized the harm to the more intangible extension of the person. As society migrates to more digital existences, the criminal law has adapted to modify crimes, such as cyber stalking and harassment, cyber bullying, and online threats. ${ }^{85}$ The criminal law's recognition of the digital extension of self as a source of harm becomes clearer. It also officially recognizes this form of harm, and creates more support for the proposal of this article.

"Stalking" is defined as the culpable committing of a series of actions such as following or harassing that cause or are intended to cause fear. ${ }^{86}$ In the late $1990 \mathrm{~s}$, its criminalization began after the death of a well-known actress who had been stalked for two years. Prior to the legislative response, law enforcement was somewhat unable to respond because any one of the acts alone was not likely illegal. Therefore, law enforcement found itself in the unenviable position of being

${ }^{82}$ See Sen. Judiciary Comm. Statement to Sen. Comm. Substitute for Sen. No. 1031, 1 (N.J. 1998).

83 See generally S.B. 1255, 2013-2014 Gen. Assemb., Reg. Sess. (Cal. 2014).

84 H.B. 260, 147th Gen. Assemb., Reg. Sess. (Del. 2014).

85 See generally Lipton, supra note 32.

86 NIJ REPORT TO CONGRESS, supra note 49, at 4. 
unable to respond until the victim had been physically hurt, and in this case, murdered. ${ }^{87}$

The crime of stalking can be understood to recognize harms to the intangible self as well as to the physical self. Although not in all of the statutes, many states require some sort of intent to instill fear in the victim, but this intent can be inferred by knowing the contact is unwelcome. ${ }^{88}$ However, many states do not require proof that the suspect intended to cause fear as long as he intended to commit the acts that did cause fear. ${ }^{89}$

The purpose of engaging in stalking is not always to cause physical harm to the victim. It can be driven by anger or a desire for contact. It has been found that defendants engage in this behavior for a variety of reasons including revenge, control, contact, or mental health issues. ${ }^{90}$ The harms experienced by victims of this relentless activity can include fear, hypervigilance, disrupted sleep, helplessness, anxiety, and PTSD. ${ }^{91}$

In a post-digital world, the commission of these crimes has migrated to cyberspace. "Cyberstalking" refers to situations in which the offender uses technologies such as email, texting, or devices to create a level of intimidation, harassment, and fear in his victims. ${ }^{92}$ While it may manifest within a different medium than stalking and bullying in the physical world, it is driven by the same factors and causes similar harms. ${ }^{93}$ However, these harms are more acute when they occur through the Internet because these attacks "transcend all physical boundaries, borders, and limitations." 94

The advent of the Internet also provided the platform for increased incidents of stalking because the Internet provides both anonymity and access to many potential victims. The anonymity allows the perpetrators to engage in more behaviors, to utilize more means such as email or cellular connections, and to do it at all times. "[C]yberstalking, at least from a criminological and legal perspective represents an entirely new form of deviant criminal behavior." allows for actions such as connecting the victim to pornographic web sites, so that

87 Id. at 3 .

88 Id. at 4.

$89 \quad I d$. at 6.

90 Michael L. Pittaro, Cyber Stalking: An Analysis of Online Harassment and Intimidation, 1 INT'L J. CYBER CRIMINOLOGY 180, 184, 186-87; see also NIJ REPORT TO CONGRESS, supra note 47, at 5.

91 Pittaro, supra note 90, at 191, 194. Victim Jane McCallister testified before the Senate Judiciary Committee regarding the harm she suffered due to an acquaintance stalker. She noted that she lived "in constant fear... [and felt] powerless. Though he was free to move about, I was living in a state of siege." NIJ REPORT TO CONGRESS, supra note 49, at 5.

92 Pittaro, supra note 90, at 191.

93 Id. at 191, 194.

94 Id. at 180 .

95 Id. at 182. 
she would receive pornographic images daily, stalking by proxy where a third party is used to stalk, or utilizing dangerous websites like payyouback.com, which allows stalkers to send anonymous emails. ${ }^{96}$

Notwithstanding these more pernicious harms, the criminal law responded by enacting legislation that criminalized these specific forms of stalking and harassment. All fifty states have some form of such legislation. ${ }^{97}$ Furthermore, the federal law has made it illegal to transmit threats across state lines using telephone or communication devices to harass or engage in interstate stalking. ${ }^{98}$

Thus, the evolution of the law reflects an implicit recognition of the extension of self and the need to criminalize harming that extension. The migration from stalking and harassment model to a cyberstalking model also endorses the concept that the social harm is distinct and arguably greater in the digital world than in the physical.

\section{Identity Theft}

Identity theft exemplifies a crime that has emerged in modern times, has been significantly altered in the digital era, and recognizes the digital extension of self. Many versions of identity theft can occur, which can blur its exact definition. This article refers to "identity theft" as the obtaining and/or utilizing of pieces of personal information about another, often personally identifying information such as a social security number, for fraudulent purposes that include but are not limited to obtaining money or credit, avoiding criminal charges, or obtaining other documents. $^{99}$ With the evolution of one's online identity, simply more avenues exist through which to steal one's identity, more ways exist to utilize that identity, and, therefore, more opportunities to harm the actual person. ${ }^{100}$ This is compounded by the reality that one's digital reputation is increasingly important to one's existence. With this digital manifestation of harm, the criminal law has

$96 \quad$ Id. at 185.

$97 \quad I d$. at 192 .

9818 U.S.C. $\$ 875$ (c) (1994) (sentencing a person who "transmits in interstate or foreign commerce any communication containing any threat to kidnap any person or any threat to injure the person of another" to be fined and/or imprisoned for five years); 47 U.S.C. $\S 223$ (2013) (criminalizing obscene or harassing telephone calls in the District of Columbia or interstate or foreign communications).

99 Beth Givens, Identity Theft, How It Happens, Its Impact on Victims, and Legislative Solutions before the Sen. Judiciary Subcomm. on Technology, Terrorism, and Gov't Info (July 12, 2000)(written testimony) [hereinafter Identity Theft, How It Happens] (written testimony of Beth Givens, Director, Privacy Rights Clearinghouse).

100 Technology has changed the landscape: items on the Internet supposed to be private are accessible (email, text) to data harvesters, worms, keystroke loggers. Conversely, information voluntarily share is at risk to being obtained by data harvesters, retailers, or scrapers of information. Sally M. Guy \& Karen D. Morgan, Dep'T of Legislative Serv., Identity Theft in Maryland (2013). 
implicitly recognized the harm caused by the injury to the digital presence, in this case, the person's identity.

Various social harms have been associated with identity theft. This crime was once categorized only as a property crime due to the financial losses experienced, not by the person whose identity was stolen, but by the commercial entity that suffered the financial loss of a fraudulent credit card or checking account. Today, the criminal law recognizes that it is the harvesting of this personally identifiable information that is the problem, not just the thefts, which may result from this crime. Offenders use or sell the stolen information so that criminals can use it for many purposes such as obtaining healthcare, prescription drugs, driving licenses, and avoiding criminal convictions or offender registration, just to name a few. Consequently, this criminal activity causes many more types of harm including emotional scarring from the personal violation and helplessness that results from trying to contain the damage and regain one's identity, the risk of false arrest, or the risk of IRS accusations of under payment. ${ }^{101}$

Many states recognize identity theft as a property crime and this is manifested in a variety of ways. While some states include this crime within its larceny statute, ${ }^{102}$ others include property concepts within its elements ${ }^{103}$ or within its sentencing provisions. ${ }^{104}$ Property harms extend far beyond financial loss to the institution. The actual victim spends more than 175 hours and thousands of dollars in the attempt to reclaim his or her name. ${ }^{105}$

However, the harm caused by identity theft is not limited to property interests. ${ }^{106}$ Several states recognize the reality that identity theft victims suffer a panoply of harms. These harms can include assuming credentials of a person to avoid criminal arrest or lead to the arrest of another. ${ }^{107}$ The reputational nature of the harm is also explicitly addressed in several states. ${ }^{108}$ They can also include the anxiety, frustration, and time spent trying to regain credit history and financial stability. ${ }^{109}$

101 Identity Theft, How It Happens, supra note 99.

102 E.g., R.I. GEN. LAWS $§ 11-41-4$.

103 E.g.,720 Ill. COMP. STAT. 5/16-30 (requiring the intent to obtain property or commit a felony); R.I. GEN. LAWS $\S 11-41-4$ (including, but not limiting liability to, situation in which a defendant "receives money or other property"); LA. REV. STAT. ANN. §14:67:16.

104 E.g., KAN. STAT. ANN. § 21-6604 (allowing restitution for those who suffer financial loss due to debt created by defendant); see also LA. REV. STAT. ANN. § 14:67:16.

105 S.B. 425, 2003 S. Comm., Reg. Sess. (Cal. 2003) (citing Privacy Rights Clearinghouse and Federal Trade Commission).

106 Even the jurisdictions that seem to focus on the injuries to property, recognize the nonproperty harms through other statutes. For example, California's criminal code addresses false impersonation of another, acquiring of another's credit information, or the publishing of information of this type under separate code sections. CAL. PenAL. CodE $\S \S 529,484(\mathrm{e}), 484(\mathrm{j})$ (2001).

107 N.C. Gen. Stat. §§ 14-113.20(a), 14-113.22(a)(i); Miss. CodE AnN. § 97-45-27.

108 E.g., Wis. STAT. $\S \S 943.201(2), 943.203$.

109 Identity Theft, How It Happens, supra note 99. 
However, of most relevance to this article, is the recognition of the more intangible harms that stealing one's digital presence may cause to the actual person. This is most clearly demonstrated in the statutes that discuss emotional harm or the intent to cause emotional harm. ${ }^{10}$ Some of the broader statutes, however, simply forbid such activity when personal information is obtained or used with any intent to harm. ${ }^{111}$ Under federal law, an offender must simply have the intent to commit an unlawful act. ${ }^{112}$

At the crux of this broadening conceptualization of the harm of identity theft is the understanding of the compounding harms created by the Internet and the extension of self. Prior to the rise of the digital world, the crime did take place, but it required a dishonest employee or person to obtain the information physically through confiscating a credit card, receipt, or mail. ${ }^{113}$ Today, the information is widespread throughout the Internet or in possession of third parties inadequately protected from hacking. ${ }^{114}$ "The advent of personal and mobile technology has been a game changer, however, and has altered identity theft from one in which its prevalence ebbs and flows ... to one with exponential growth." growth comes the growth of social harms. . The criminal law is recognizing that those violations of one's digital presence directly affect the actual person.

\section{THE THIRD DiMENSION OF VICTIMIZATION: RECOGNIZING THE DigITAL EXTENSION}

As technologies develop, the reach of our lives and our resultant connectedness are expanding into the digital realm. All aspects of contemporary American life have migrated in this way. That extension of ourselves is intertwined with who we are. Consequently, we are responsible for the actions of our digital self since it is an extension of our physical selves. Similarly, we also feel pain and suffering when it is harmed or exploited. The nature of the harm is unique. It is geographically and temporally limitless. As such, it demands a specialized recognition and response.

That extension of ourselves is a socially valuable interest and the law should strive to protect it. Structurally, the criminal law must reflect this development. No longer should victims have to argue by analogy to establish a social harm. While criminal laws have adjusted and expanded on a crime-by-crime basis to encompass modern versions of victimizations, it is this piecemeal and uneven

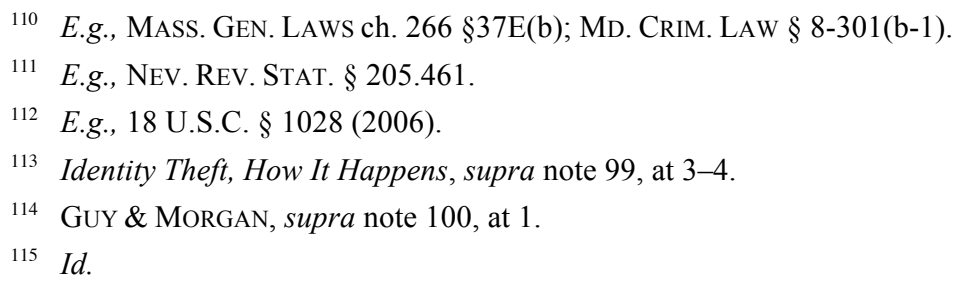


approach that leaves gaps in the law. Moreover, such an approach fails to capture modern life which is lived in part on a third dimension-a digital one. This is more than a temporary change. Similar to the rise of electricity or the motor vehicle, this digital revolution has literally altered how the world functions, life is lived, and, therefore, how people are victimized. It is time for a more comprehensive overhaul.

This shift demands a third dimension be added to the familiar propertypersonal crime dichotomy common in criminal law codes for personal victimization. This should result in a separate section of criminal codes for crimes against the digital person as an extension of self. The previous crime by crime approach to reform is inadequate. A major overhaul of criminal codes is necessary because it more accurately reflects the social harm, it signifies the importance of these infractions, and it is not a disruptive alteration, but the culmination of a recognition that criminal victimization occurs in this realm.

\section{A. A Separate Section Reflects the Social Harm}

The harms of cyber victimization are unique. ${ }^{116}$ As discussed, these exploitations of the digital self can harm victims in ways that surpass the contemplated harms experienced in the non-digital world. The omnipresence of cyberspace, the scope of its influence, and the quantity of people that can be reached all conspire to magnify harm to a previously unforeseen level.

Yet, when prosecutors and courts seek to redress the injuries suffered, they are forced to utilize crimes or concepts from a different time. By enacting a separate section to criminal codes, legislatures no longer must seek to put the proverbial square peg into the round hole, trying to expand current criminal law to meet new demands. While some may argue a separate section of crimes might divorce these crimes from their historical predecessors - such as separating cyber stalking from stalking - this separation is the wiser path. ${ }^{117}$ Although related, the harms of cyber victimization are substantially distinct and more profound than their analogies in the physical world. As such, creating a separate section in criminal codes for these offenses conveys the significance of the criminal conviction and the unique harms of these types of victimization. Moreover, a separate section also offers an important statement about the magnitude of the harms.

\footnotetext{
${ }^{116}$ See supra Section III.

117 See Paul H. Robinson \& Michael T. Cahill, The Accelerating Degradation of American Criminal Codes, 56 Hastings L.J. 633, 635 (2005) (criticizing piecemeal modification of criminal codes).
} 


\section{B. A Separate Section Conveys the Seriousness of the Infraction}

As a criminal conviction represents the moral condemnation of a community, so do criminal codes represent the values of a community. A critical aspect of an effective criminal code is that it groups offenses together in systems of related crimes, not simply adding new crimes as a result of random politically supported punishments. ${ }^{118}$

A separate chapter conveys two important aspects of criminal law and society. It demonstrates that a community recognizes the significance of such victimizations and approaches these crimes with seriousness. Categorizing the modern crimes by harm experienced rather than harm intended underscores the social value compromised. Because the social harm of digital victimization is uniquely pernicious and involves the exploitation of the digital self, these crimes should be together under one section.

\section{A Separate Section Continues the Modern Development of Criminal Law}

Such a structural change also conveys a modernity necessary in criminal law. A separate chapter communicates not only an awareness of changing times, but a recognition that the trend of modern living is to become more digital. Therefore, such a chapter communicates this modernity and demonstrates the criminal law is current, both in its understanding of the crime and its expectations of where society will migrate in the future.

This restructuring is the most productive way for our criminal law to move forward. For a criminal code to be recognized as legitimate, it must reflect contemporary values. ${ }^{119}$ That is not to say a criminal code should be amended with each trend. Two circumstances indicate a need for change in criminal codes. They should be amended when new forms of victimizations develop and the current law fails to protect. Secondly, they should be amended when sustained structural changes in society occur. Both conditions are present today.

Society has seen laws adapt to major societal changes which lead to new ways of victimization. For example, a motor vehicle code was created when automobiles grew in stature to become a staple in American life. The ubiquity of automobiles meant that they were more than a passing fad, but an alteration of modern American life, not only for those who owned vehicles, but for all people. It expanded a permanent new way in which people could be victimized and

${ }^{118}$ See Paul Robinson, Reforming the Federal Criminal Code: A Top Ten List, 1 BufF. CRIM. L. REV. 225, 233 (1997) ("A code should adopt a system of offenses, in which offenses are designed to work together. Offenses should complement each other.").

119 Robinson, supra note 118, at 264 (noting the necessity of the criminal law earning a "reputation as a reliable statement of what the community... perceives as condemnable"). 
demanded the law reflect that reality. ${ }^{120}$ The same is true for the advent of the Internet and other digital communications. The Internet is today a "vital infrastructure" in America. ${ }^{121}$ It is "essential to functioning in today's society." "122 If an essential component of life, victimization occurs within it. ${ }^{123}$ Therefore, it is equally as essential that criminal codes reflect this new reality and protect citizens as they function in that society grows and develops. Such victimizations will only increase as we grow. Spending more time online, translates to more opportunity for crimes and more types of crime. Therefore, society must recognize that trend and have a criminal code that reflects it. The old crimes can only be analogized to a finite amount of changes. Ultimately, however, with individual's lives migrating online, the criminal law must have a presence there.

\section{CONCLUSION}

The law is organic and nowhere is this felt more acutely than the criminal law. The number of methods that can be used to victimize a person is limited only by the imagination of the deviant mind seeking to cause such social harm. Therefore, this body of law is constantly adapting to new forms of victimization. Technology has permanently altered how Americans live. The criminal law should reflect this fundamental shift as well.

The purpose of the criminal law is to protect socially valuable interests. Jurisprudence in other areas indicates that the law has recognized crimes that protect interests beyond the person or property, but extensions of the self. It has further acknowledged the unique harms experienced by the victim when that extension is the target of misdeeds. The criminal law must explicitly convey that by abandoning the two dimensional construct of crimes against the individual and embrace this third dimension. By recognizing the social harms caused by targeting the online extensions of ourselves, criminal codes will advance the very purpose of the criminal law to protect citizens.

120 DeWitt Blashfield, Blashfield's Cyclopedia of Automobile Law iii (1927) (“The enormous increase in the volume of traffic upon the highway, because of the new machine and the consequent clash of interests and wills...called upon legislature to establish traffic code.").

${ }^{121}$ Unleashing the Wireless Broadband Revolution, Memorandum of President, 75 Fed. Reg. 38387 (June 28, 2010).

${ }^{122}$ United States v. Sealed Juvenile, 781 F. 3d 747, 756 (2015).

${ }^{123}$ Charlotte Decker, Cyber Crime 2.0: An Argument to Update the United States Criminal Code to Reflect the Changing Nature of Cyber Crime, 81 S. CAL. L. REv. 959, 961 (2008) (noting that increased networking creates opportunities for victimization). 